\title{
Distributional range expansion and first record of the parasitic wasp Horismenus liturgusae Hansson \& Schoeninger, 2014 (Hymenoptera, Eulophidae) on Liturgusa maya Saussure \& Zehntner, 1894 (Mantodea, Liturgusidae) from Ecuador
}

\author{
Pablo Sebastián Padrón ${ }^{1 *}$, Pamela Estefanía Andrade ${ }^{1}$, Lucía Vanessa Ortiz ${ }^{1}$ \\ Madeleine Carmen Campaña ${ }^{1}$ \\ 1 Entomology Laboratory, Museo de Zoología, Universidad del Azuay, Cuenca, Ecuador • PSP: sebastianpadronm@yahoo.com (1) https://orcid. \\ org/0000-0001-9104-1657 • PEA: pamandr2001@es.uazuay.edu.ec (D https://orcid.org/0000-0002-9591-3106•LVO: luciivom@es.uazuay. \\ edu.ec (1) https://orcid.org/0000-0002-9534-2112•MCC mcampana38@es.uazuay.edu.ec (1) https://orcid.org/0000-0001-7987-8681 \\ * Corresponding author
}

\begin{abstract}
The presence of the parasitic wasp Horismenus liturgusae Hansson \& Schoeninger, 2014 is recorded for the first time in Ecuador. This new record significantly expands the known distributional range of the species by more than 2000 km west of its type locality in Manaus, Brazil. In addition, the Neotropical bark mantid Liturgusa maya Saussure \& Zehntner, 1894 is reported as a host, and Horismenus specimens were reared from the mantids ootheca.
\end{abstract}

Keywords

Amazon, Chalcidoidea, Morona Santiago, Neotropics

Academic editor: Sandor Buys | Received 18 March 2021 | Accepted 17 April 2021 | Published 27 April 2021

Citation: Padrón PS, Andrade PE, Ortiz LV, Campaña MC (2021) Distributional range expansion and first record of the parasitic wasp Horismenus liturgusae Hansson \& Schoeninger, 2014 (Hymenoptera, Eulophidae) on Liturgusa maya Saussure \& Zehntner, 1894 (Mantodea, Liturgusidae) from Ecuador. Check List 17 (2): 709-712. https://doi.org/10.15560/17.2.709

\section{Introduction}

Parasitic wasps are a fascinating, ecologically important, diverse, and taxonomically challenging group of insects (Heraty et al. 2013; Munro 2011) that are especially diverse and dominant in the Neotropics (Murray and Heraty 2019). The genus Horismenus Walker (1843) is a predominantly Neotropical parasitic wasp group (Kenyon et al. 2015) which currently includes more than 400 species (Hansson 2009; Kenyon et al. 2015). The species are parasitoids or hyperparasitoids on a variety of hosts, including mantids (Hansson 2009; Hansson et al. 2014). Records of mantid parasitoids are generally scarce, and this is especially true and evident in the Neotropics where few reports have been published (Ehrman 2002; Rivera 2003; Hansson et al. 2014; Martínez et al. 2017; Falcon and Padrón 2019; Santos Murgas et al. 2019). This might seem contradictory to the high species diversity of mantids and parasitic wasps that can be found in this region (Agudelo et al. 2007; Arias and Delvare 2003). Therefore, new information, including new distribution records such as the one presented here, are important for a better understanding of the group as a whole. 


\section{Methods}

The specimens reported here were reared from an ootheca of the bark mantid Liturgusa maya Saussure \& Zehntner, 1894 (Fig. 1B, C) which was attached to the bark of the tree Cedrela odorata L. approximately $1 \mathrm{~m}$ above ground. It was found during a search for mantids carried out at Parque Regional Botánico del Cantón Sucúa (PRBCS), Morona Santiago province, Ecuador (Fig. 1A). The ootheca was collected and stored in a plastic rearing cage and transported to the city of Cuenca $2500 \mathrm{~m}$ a.s.l. Azuay province in the Andes for further study. After seven days 36 mantid nymphs hatched from the ootheca, and then after 10 additional days, 67 adults of a parasitic wasp were found in the rearing cage where the ootheca was kept. Specimens are deposited in the Entomology Collection of the Museo de Zoología de la Universidad del Azuay (MZUA), Cuenca, Ecuador, and are preserved and stored in $70 \%$ ethanol. The preserved wasps were analyzed at the Entomology Laboratory at Universidad del Azuay in Cuenca. For morphological measurements, a stereomicroscope Nikon SMZ745T with MSHOT software was used.

Photos of the specimens were taken using a Canon 5D Mark III camera with a Canon MPE $65 \mathrm{~mm}$ lens and a Mitutoyo $10 \times$ and Nikon $20 \times$ microscope lens attached to a tube system. The final images were composed from several individual photos combined through a focus stacking technique using Zerene Stacker Software. The final plates were assembled using Photoshop CS6.

\section{Results}

Adults of the parasitic wasp Horismenus liturgusae Hansson \& Schoeninger, 2014 (Eulophidae) were identified. The host was identified as L. maya based on nymphs that hatched from the ootheca and from adults that were collected previously from the same area.

Material examined. ECUADOR - Morona Santiago Province, Sucua/ Parque Regional Botánico del
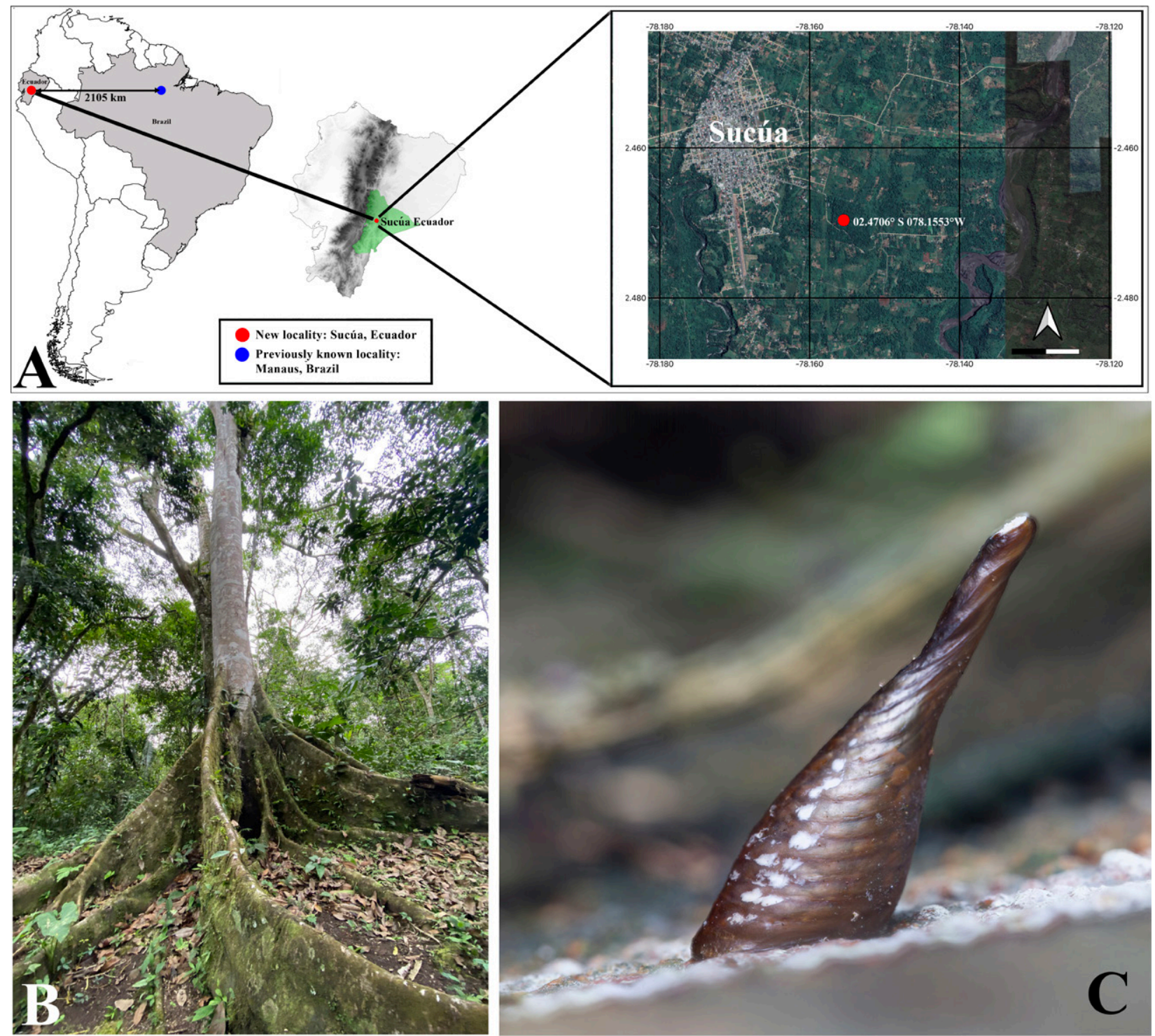

Figure 1. New locality record of Horismenus liturgusae. A. Previously known occurrence in Manaus and the new record at PRBCS in Sucúa, Morona Santiago Province, Ecuador. B. Habitat where the mantid ootheca was found. C. Ootheca of Liturgusa maya in situ. 
Cantón Sucúa, $02.4707^{\circ} \mathrm{S}, 078.1554^{\circ} \mathrm{W}$, alt. $880 \mathrm{~m}$ a.s.1.; 03.II.2021; P.S. Padrón leg.; 67 specimens, MZUAEN47158 to MZUA-EN47224.

Identification. Identification of the specimens was corroborated with the original description based on external morphological characteristics found on the head: antennal scrobes joining below frontal suture, eyes very large and frons very narrow; mesosoma: mesoscutum with engraved reticulation, mesoscutum and scutellum metallic dark; and gaster in males conspicuously hairy (Fig. 2) and later confirmed by Dr. Christer Hansson Lund University.

\section{Discussion}

Horismenus liturgusae was originally described from Manaus, Brazil, and the description was based on specimens reared from an ootheca of the bark mantid genus Liturgusa Saussure, 1869, but the species was not identified. Our female specimens show small differences from the female holotype, such as the eyes appearing to be slightly smaller and the space between them larger (Fig. 2). However, these small variations can be attributed to geographical variation.

The genus Liturgusa includes 11 species and is a common and sometimes abundant group of Neotropical forest mantids (Svenson 2014) which are commonly known as bark mantids due to their similarity with bark and their adapted behaviour to dwell on tree trunks where they actively hunt for prey. Liturgusa maya has a broad distribution in the Neotropics and is very versatile in the use of habitats, from forests in a good state of conservation to heavily degraded places (Svenson 2014).

So far only three records of parasitoid wasps have been reported for the genus Liturgusa, and therefore new information about parasitic wasps is especially important. Ehrman (2002) mentioned an unidentified hymenoptera as parasitoid of Liturgusa; Hansson, et al. (2014), reported and newly described $H$. liturgusae from Brazil as a parasitoid of an unidentified species of the genus Liturgusa. Finally, Santos Murgas et al. (2019), reported a species of Anastatus sp. (Eupelmidae) as the parasitoid of Liturgusa cf. maya from Panama. Our report is the fourth record of parasitism for the genus Liturgusa. This record constitutes the first from Ecuador and represents a significant increase of the distribution range $H$. liturgusae, and it is also the first record for a named species of Liturgusa as the host. The locality where the ootheca and the wasps were collected, PRBCS, is located at least $2100 \mathrm{~km}$ west of the type locality of $H$. liturgusae in Manaus, Brazil (Fig. 1). The forest of PRBCS constitutes a protected remnant of 26 ha of secondary forest in the process of restoration and is classified as "evergreen foothill forest of the southern Eastern Cordillera of the Andes" (Ministerio del Ambiente del Ecuador 2013). The eulophid fauna is still very poorly known in Ecuador (Hansson 2010), where many new records and new
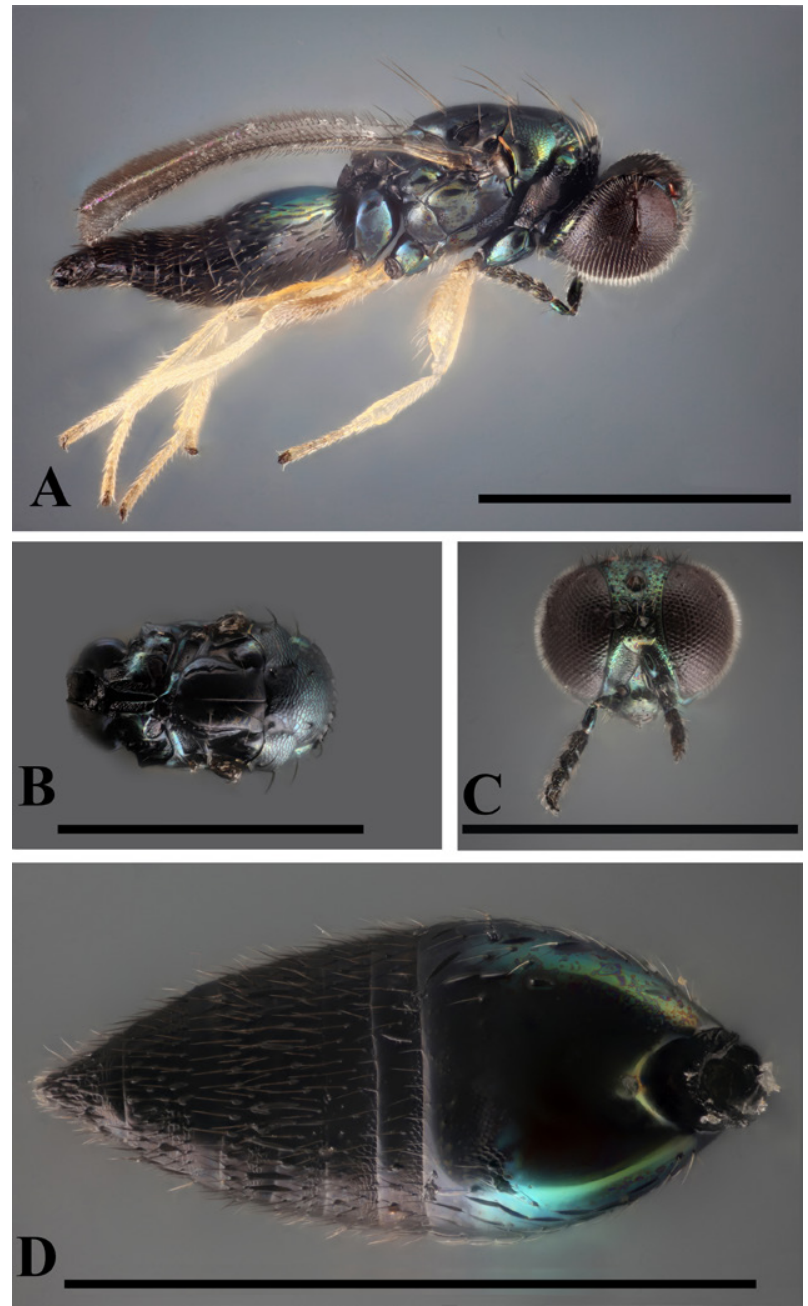

Figure 2. Horismenus liturgusae female. A. Habitus lateral view. B. Mesosoma dorsal view. C. Head frontal view. D. Gaster dorsal view. Scale bars $=1 \mathrm{~mm}$.

species would be discovered if diversity inventories were performed. So far only 15 species of the genus Horismenus have been recorded from Ecuador H. albiscapus Hansson, 2009; H. chydaeus Hansson, 2009; H. corbus Hansson, 2009; H. dulcis Hansson, 2009; H. elineatus Schauff, 1989; H. erasmus Hansson, 2009; $H$ eumantis Hansson, 2009; H. eurys Hansson, 2009; H. leius Hansson, 2009; H. napus Hansson, 2009; H. nigrocyaneus (Ashmead, 1894); H. nyctiscapus Hansson, 2009; H. platynotus Hansson, 2009; H. rhanis Hansson, 2009 and H. striatus Hansson, 2009 (Ashmead, 1894) (unpublished data, Natural History Museum, London, March 2021).

Finally, this new information adds to the knowledge of host-parasitoid interactions and potential impact on the survival, population dynamics, and regulation of hosts, which are still very unclear but an interesting and promising area for future research.

\section{Acknowledgements}

We thank Dr. Christer Hansson, Lund University, who helped us in the identification of the parasitoid and provided valuable comments and information for the manuscript. 
We also thank the Gobierno Autónomo Descentralizado of Sucúa. This research was funded in part by the Universidad del Azuay Research Funding 2020-2021. Collecting of specimens were conducted under the collecting permit obtained from the Ministerio del Ambiente. Finally, we would like to thank the reviewers.

\section{Authors' Contributions}

All authors contributed to writing and revision the final manuscript. Conceptualization: PP. Data curation: PP. Funding acquisition: PP. Investigation: PP, PA, LO, MC. Methodology: PP. Writing - original draft: PP, PA, LO, MC. Writing - review \& editing: PA, LO, MC.

\section{References}

Agudelo AA, Lombardo F, Jantsch LJ (2007) Checklist of the Neotropical mantids (Insecta, Dictyoptera, Mantodea). Biota Colombiana 8 (2): 105-158. https://doi.org/10.13140/RG.2.1.3877.8086

Arias DC, Delvare G (2003) Lista de los géneros y especies de la familia Chalcididae (Hymenoptera: Chalcidoidea) de la región Neotropical. Biota Colombiana 4 (2): 123-145.

Ehrman R (2002) Mantodea-Gottesanberinnen der Welt. Natur und Tier-Verlag, Münster, Germany, 519 pp.

Falcón JM, Padrón PS (2019) Historia natural de Pseudopogonogaster hebardi (Terra) (Mantodea: Thespidae), una especie de mantis liquen polifénica del sur de Ecuador. Revista Chilena de Entomología 45 (2): 221-235. https://doi.org/10.35249/rche.45.2.19.6

Hansson C (2002) Eulophidae of Costa Rica, 1. Memoirs of the American Entomological Institute 67: 1-290.

Hansson C (2009) Eulophidae of Costa Rica, 3, the genus Horismenus. Memoirs of the American Entomological Institute 82: 1-916.

Hansson C (2010) Catalogue of the Eulophidae in the Neotropical region. http://www.neotropicaleulophidae.com/pdfs/Catalogue.pdf. Accessed on: 2021-4-21.

Hansson C, Pádua DG, Schoeninger K, Agudelo AA, Oliveira ML (2014) A new species of Horismenus Walker (Hymenoptera, Eu- lophidae) from ootheca of Liturgusa Saussure (Mantodea, Liturgusidae) from Central Amazonas, Brazil. Journal of Hymenoptera Research 37: 53-60. https://doi.org/10.3897/jhr.37.6729

Heraty JM, Burks RA, Cruaud A, Gibson GAP, Liljebad J, Munro J, Rasplus J-Y, Delvare G, Janšta P, Gumovsky A, Huber J, Woolley JB, Krogmann L, Heydon S, Polaszek A, Schmidt S, Darling DC, Gates M, Mottern J, Murray E, Dal Molin A, Triapitsyn S, Baur H, Pinto JD, van Noort S, George J, Yoder M (2013) A phylogenetic analysis of the megadiverse Chalcidoidea (Hymenoptera). Cladistics 29 (5): 466-542. https://doi.org/10.1111/cla.12006

Kenyon SG, Buerki S, Hansson C, Alvarez N, Benrey B (2015) Uncovering Cryptic Parasitoid Diversity in Horismenus (Chalcidoidea, Eulophidae). PLoS ONE 10 (9): e0136063. https://doi.org/10.1371/ journal.pone.0136063

Martínez-Luque EO, Martínez-Mandujano V, Gonzáles-Martínez FJ (2017) Primer registro de Podagrion mantis Ashmead (Chalcidoidea: Torymidae) como parasito de ootecas de Stagmomantis limbata Hahn (Mantodea: Mantidae) para el estado de Zacatecas, México. Entomología Mexicana 4: 90-95.

Ministerio del Ambiente del Ecuador (2013) Sistema de Clasificación de los Ecosistemas del Ecuador Continental. Subsecretaría de Patrimonio Natural. Quito, Ecuador, 235 pp.

Munro JB, Heraty JM, Burks RA, Hawks D, Mottern J, Cruaud A, Rasplus JY, Jansta P (2011) A molecular phylogeny of the Chalcidoidea (Hymenoptera). PloS ONE 6 (11): e27023. https://doi. org/10.1371/journal.pone.0027023

Murray EA, Heraty JM (2019) Neotropical ant parasitoids (Hymenoptera: Eucharitidae): interpreting taxonomy, phylogeny and divergent morphologies. Systematic Entomology 45 (2): 464-480. https://doi.org/10.1111/syen.1240 7

Rivera J (2003) Discovery of Podagrion brasiliense Howard, 1894 (Hymenoptera: Torymidae) as a parasitoid of the ootheca of $\mathrm{Mu}$ sonia surinama (Saussure, 1869) (Mantodea: Thespidae). Revista Peruana de Entomología 43: 1-20.

Santos Murgas A, Cambra RA, Abrego LJC (2019) Brachymeria annulata y Anastatus sp. (Hymenoptera: Chalcidoidea) parasitoides respectivos de Historis odius (Lepidoptera: Nymphalidae) y Liturgusa sp. (Mantodea: Liturgusidae). Tecnociencia 21 (1): 57-64.

Svenson GJ (2014) Revision of the Neotropical bark mantis genus Liturgusa Saussure, 1869 (Insecta, Mantodea, Liturgusini. ZooKeys 390: 1-214. https://doi.org/10.3897/zookeys.390.6661 